\title{
Knowledge management and organizational innovativeness in Iranian banking industry
}

Maryam Bidmeshgipour*

Faculty of Management and Human Resource Development

Universiti Teknologi Malaysia, Malaysia

E-mail: bidmeshgi@gmail.com

\author{
Wan Khairuzzaman Wan Ismail \\ International Business School \\ Universiti Teknologi Malaysia, Malaysia \\ E-mail: mwkhair@ibs.utm.my
}

\section{Rosmini Omar}

International Business School

Universiti Teknologi Malaysia, Malaysia

E-mail: rosmini.omar@minotstateu.edu

*Corresponding author

\begin{abstract}
Knowledge management has changed its nature from theoretical concept to an instrument that assists innovativeness. The originality of this study lies in its purpose to explore issues of knowledge management and its relation to the innovativeness of organizations. The study focuses on three selected Iranian banks (in public and private sector), an industry and a setting that has received less attention by researches so far. This paper studies the effectiveness of managers' mindset in leading or misleading the organizations to achieve organizational innovativeness through $\mathrm{KM}$. Based on a questionnaire survey, the authors argue that applying knowledge management makes it simpler to achieve the innovativeness in organizations. What we found significant in this study is that employees, provided with appropriate training and mentoring opportunities to generate novel ideas, would create new services in banking. The mindset of bank managers about their human resources absorbs diversity of opinions and provides equal opportunity for all employees to present ideas.
\end{abstract}

Keywords: Knowledge management; Innovativeness; Human based resources; Leadership view

Biographical notes: Maryam Bidmeshgipour is a $\mathrm{PhD}$ student (Management) at the Universiti Teknologi Malaysia.

Wan Khairuzzaman Wan Ismail is an Associate Professor at the Universiti Teknologi Malaysia.

Rosmini Omar is an Associate Professor at the Universiti Teknologi Malaysia. 


\section{Introduction}

Previous studies present valuable findings to indicate that there are some types of assets located in the minds of employees. Knowledge is one of them. Without human cognition, there is no knowledge creation (Cijsouw, Jorna, Rakhorst, \& Verkerke, 2007). One alternative to manage people is through an environment in which knowledge can be created, shared, discovered, captured and validated. Thus, managers' inquiries on when, how and why they have to invest in knowledge is very crucial.

The increasing plethora of interest for innovation and strategic management puts knowledge at the center of attention (Darroch, 2005; Davenport, De Long, \& Beers, 1997; Grant, 1996a; Lengnick-Hall \& Lengnick-Hall, 2002, Hargadon, 1998; Nonaka, \& Takeuchi, 1995; Swan, Newell, Scarbrough, \& Hislop, 1999). The necessity to compete for knowledge (Audretsch \& Thurik, 2004) is due to the nature of knowledge that is hard to replicate (Chirico, 2008) and among other tools, that an organization may acquire this one is hard to imitate by other organizations. Several definitions and conceptions of KM exist (Alavi \& Leidner, 2001; Coombs, 1998; Davenport, De Long, \& Beers, 1997; Nonaka, \& Takeuchi, 1995; Probst, Raub, \& Romhardt, 1999). These different approaches to KM concentrate on the creation, diffusion, storage and application of either existing or new knowledge (Coombs, 1998). Literature shows that knowledge is (1) often embedded in employees; (2) has features of a public good (Jaffe, 1986; Liebeskind, 1997); and (3) can hardly be bought in the market (Hall \& Mairesse, 2006). These features for knowledge make it hard to capture. It is also sophisticated to manage, as managers have to be able to capture and acquire it to bring their organizations to innovative edge. Although the importance of knowledge management is widely accepted but the empirical works that show the relationship of KM and innovativeness is still in its infancy (Hall \& Mairesse, 2006). There is a prominent gap for detailed investigation of knowledge management existence and implementation in organizations.

Thousands of reports and studies have elaborated on the KM practiced in banking systems of developed countries. However, there are very rare studies about the level of practicing and considering $\mathrm{KM}$ as a merit not cost in Middle Eastern countries, specifically Iran. The contribution of this study lies in its effort to enhance Iranian banking industry understanding on the existence of KM practices. Such understanding is crucial for their quest for innovation. Hopefully, it can also generate lessons for other industries in Iran who are looking for more secure ways to get the most benefit from their KM practices. The other uniqueness of this study is its KM perspective through employees' perception. The reason is that well-established organizational KM plans, without employees' support may lead to failed implementation.

\section{Theoretical foundations}

The primary step of implementation lies in designing policies and strategies and ascertains that they are in good fit and alignment with our goals. High-level documents such as the department's statement of strategy and annual report outline the goals and objectives of the various sectoral goals and policies, with KM being presented as the corporate sectors' first strategic objective. Linking KM and business processes, and the support of senior managers are two pillars of critical success for KM (Heisig, 2009) and for effective deployment of corporate portal (Benbya, Passianten, \& Belbaly, 2004). For instance, at the school level, in order to put KM into action, it is crucial to understand teachers' perception of KM at the outset (Chu, Wang, \& Yuen, 2011). Gaining senior managers' support can be achieved by linking the deployment of information 
technologies to economic and productivity values (Turban, Leidner, McLean, \& Wetherbe, 2008). Likewise, end users' perceived KM systems (KMS) benefits are a significant determinant of their use (Wu \& Wang, 2006). It is significant, however, that knowledge management/sharing is not listed among the strategic objectives or actions for non-corporate sectors/divisions (Butler \& Murphy, 2004). Popular management ideas are translated simultaneously into corporate policy and organizational practices. Policy and procedures are consumed and interpreted by individuals in light of their own objectives (autonomy, training and coaching) which produces situated practice and is expressed through making-do, bricolage and resistance tactics (Corbett-Etchevers \& Mounoud, 2011). Innovativeness has recently been inserted in the every corporate goal, as it is among the achievements that brings organizations competitive advantage and provides it with distinguished fortunes. The Human Resource Services Report (PricewaterhouseCoopers Human Resource Services, 2006) undoubtedly demonstrates that clear correlations exist between high investment in learning and competitive business results, thus the management of talent and learning can only be achieved through the alignment of strategy, learning and technology (Klett, 2010). Big companies are more likely to have a whole range of KM activities and to have some kind of explicit or conscious KM strategy. In these companies, managers are taking the most responsibilities and are strong innovators (OECD, 2003). Considering $\mathrm{KM}$ as a tool to foster sustained competitive advantage (Earl \& Scott, 1999), necessity of inserting it in organizational policies and practices, the study elaborates on its contribution to the organizational innovativeness for both product and service. In this process and by considering that innovativeness is inserted in individuals' goals, through practicing KM, they will achieve innovativeness as organizational goal, either. Therefore, the study proposes H1 as:

\section{Knowledge management existence in policies and strategies is positively related with} innovativeness.

Following implementation KM and defining the actual results of it for the organizations, it is compulsory to evaluate the process of diffusing knowledge management message in the organization. There is no other way rather than checking the channels through which the knowledge messages of the corporate goal finds its way to our employees. We need to determine that the defined goals transformed correctly to our desired outcome that in our case is innovativeness. In this evaluation, the organization ascertains the best possible way of accurate transfer of corporate goals and converting it to the desired innovation. In the process of cascading the goals to the lower levels of the organization, leadership has been viewed among serious solutions (Muller, Valikangas, \& Merlyn, 2005). If the goal is sustainable change in the knowledge society, business and education leaders have increasingly more in common (Fullan, 2001a). Fullan (2001b) emphasizes on personal characteristics of energy/enthusiasm and hope for leaders, and five core components of leadership: moral purpose, understanding change, relationship building, knowledge creation, sharing, and coherence making. In this process, the leaders should believe the importance of their duties, comprehend the goals and have knowledge about how to inspire the employees. The leadership also might be responsible for different part of the organizations, however whoever takes the responsibility must have knowledge about his/her duty. Therefore, current study hypothesizes that:

\section{H2: Knowledge management existence in leadership is positively related with innovativeness.}

Knowledge sharing is important impetus for organization to grow and compete. A study of informal knowledge sharing among workers in Syberjaya, Malaysia shows that after twelve years of informal knowledge sharing approximately $25 \%$ of workers 
developed, gradually expanding with the establishment of multinational and international organizations. Several flagship applications have been developed in MSC Malaysia to accelerate its growth (Azudin, Ismail, \& Taheral, 2009). One of the most common ways of inspiring employees and leading them to achieve organizational goals demonstrates in paying incentives. There is increasing demand for the means of incentives that directly or indirectly motivate the employees to provide organizations with implicit knowledge and to take proactive part in knowledge management (Semar, 2004). Therefore, when it comes to the effect of incentives on individuals one can differ between extrinsic motivation and intrinsic motivation. Extrinsic incentives serve the indirect satisfaction of a need while the extrinsic approach is "a means of satisfying needs". The classic extrinsic motivation is monetary gratification whereas intrinsic motivation is just the opposite when satisfaction is achieved immediately from the activity or its aim. In the current study, we look at both sides of the incentives that might motivate the employees to participate in managing knowledge in the organizations and we investigate which one in more influential in directing employees to share their knowledge within the organization and provide it with their implicit knowledge. The study proposes that if the employees are inspired through incentives it leads them to innovativeness. We propose that:

\section{H3: Incentives given for knowledge sharing is positively related with innovativeness.}

While inserting written KM strategies in the corporate strategies are not very common, companies shift to other KM activities such as acquiring external knowledge. Collaborations with public institutions, universities and technical college are vital to keep the dynamic nature of knowledge in the organization. Knowledge acquisition from the outside marketplace and the inside employees provides opportunities for firms to recombine current knowledge and create new knowledge (Yli-Renko, Autio, \& Sapienza, 2001). A deeper application of knowledge enables firms continuously to translate their organizational expertise into embodied products (Weisberg, 2006). By effectively applying knowledge, individuals might make fewer mistakes or improve their efficiency and reduce redundancy (Gold, Malhotra, \& Segars, 2001). Organizations might then ultimately be able to speed new product development and create more innovative production processing technologies and administrative systems (Sarin \& McDermott, 2003). In the same way, another study in Singapore has evidenced that efficient knowledge acquisition and environmental dynamism influences the innovativeness of firms positively (Ojanen, 2007). Accordingly, this study proposes that:

\section{H4: Knowledge capture and acquisition is positively related with innovativeness.}

The study also investigates the existences of databases, resource dedications to obtain external knowledge and workers encouragement to participate in project teams with external experts among KM practices. Implementing knowledge management requires organizations to find methods to make their employees acquainted with the practices of knowledge management. They need to be aware of KM in formal and informal ways. Formal training such as apprenticeship might be of great importance. Informally, the experienced inspired employees will share their knowledge and experience with new or less experienced workers. Moreover, the organizations can benefit from mentoring. Mentoring is a key process for knowledge management. Apart from transferring tacit knowledge and retaining expertise within the organization, it can also help the mentee to become a recognized and accepted member of the community, by passing on corporate vision and values and improving his grasp of corporate networking (Clutterbuck, 2001). Companies should therefore consider implementing formal mentoring relationships and mentor training as an investment in the future knowledge stock of the organization. It can be implemented both formally and informally. Informal 
mentor relationships could involve assigning a guide to a new employee, or simply encouraging him to seek out a mentor. For the most part however, organizations are beginning to look at formal relationships designed to train the newcomer as quickly and effectively as possible (Frost, 2011). We have investigated different aspects of training and mentoring in practicing knowledge management and the study proposes that:

H5: Training and mentoring in knowledge acquisition and sharing are positively related to innovativeness.

Created or captured knowledge will be of most benefit only when it is communicated. Lesson learnt, experiences, good work practices articles or publications need to be stored in databases to provide employees with guidance in new projects and reduce redundancies. Effective communication and knowledge management are critical elements of successful process integration. In particular, previous research (Nonaka \& Takeuchi, 1995; Pagell, 2004) established that facilitation of effective communications of knowledge obtained from the business environment plays a key role in operational improvement. Knowledge management requires more than the simple transfer of information. For instance, the lack of curriculum-related digital resources and of a network to share them makes it difficult for teachers to share these resources for teaching in Chinese early childhood educational system (Zhou, Chen, \& Jin, 2009). To meet those organizational objectives, however, integration requires strong communication among individuals within the firm (Ruekert \& Walker, 1987; Levitt \& March, 1988; Boisot, 1995; Helfert, 2002; Pagell, 2004; Sanders \& Premus, 2005). Therefore, as the last proposition the study hypothesizes that:

H6: Communicating knowledge within the organization is positively related to innovativeness.

The proposed framework to test the hypothesis of the study is as follow:

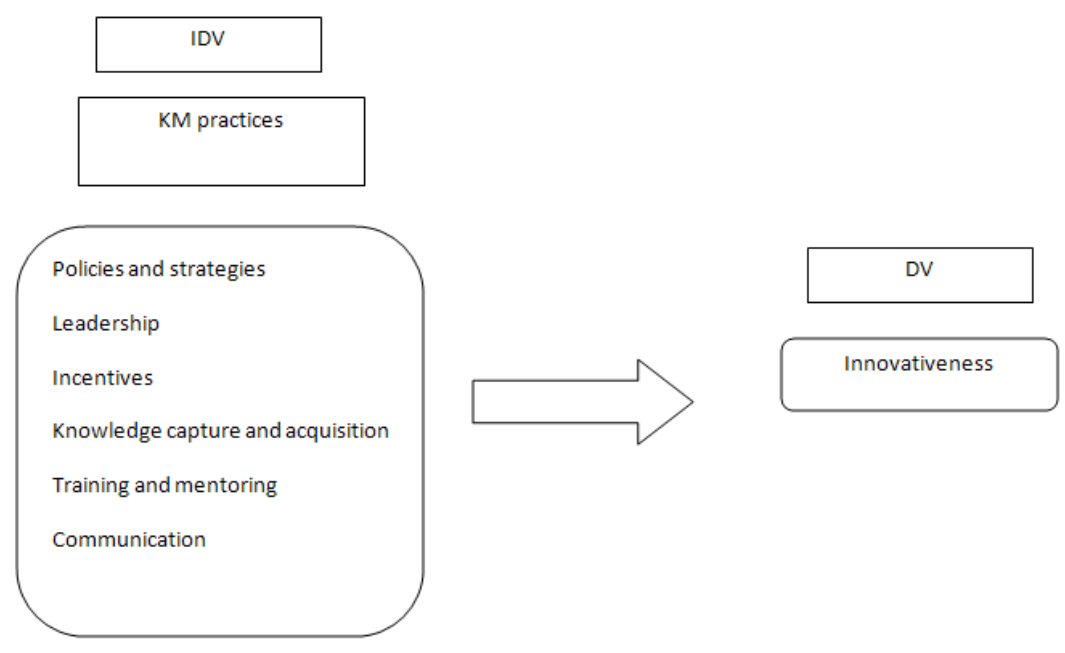

Fig. 1. Conceptual framework

Based on the conceptual framework, the dependent variable (DV) for this study is innovativeness and the independent variables (IDV) are the KM practices. 


\section{Research objectives and methodology}

Even though organizations have shown interest in implementing knowledge management methods, most companies are nervous about initiating their own KM programs (Zack, 1999). However, KM methods vary depending upon knowledge types and organizational core competence (Grant, 1996b); the primary motivation for any company must be improving business performance. The importance of $\mathrm{KM}$ in the quick changing environment, leads this study to one of the main competitive advantages for firms, which is innovativeness. The organizations are currently working to learn how to grow faster. This process of learning includes efficient capture and acquisition of knowledge that deals with knowledge management. Since the analysis and measurement of knowledge management is rather a new exercise, there is little knowledge available about how to design and conduct empirical work in this field (Edler, 2002). In order to reduce this knowledge gap there is this necessity to check KM implementation through KM practices. This study believes that the knowledge management notion produces an environment in the organization. In order to create such an environment $\mathrm{KM}$ has to be existed in the major practices of the organization. The current paper investigates it through policies and strategies, leadership, incentives paid, the way the knowledge is captured and acquired, training and mentoring applied in order to gain and share knowledge in the organization and finally the network of the communication that exists in the firm between the employees for transferring and sharing knowledge and experiences. The current paper is using the practices of a more operational mode as it believes they are more common than strategic activities (strategic, leadership, incentives), while incentives in the context of $\mathrm{KM}$ are the exception. Despite the fact that written KM strategies are not very common, companies claim to have appropriate value systems. Acquiring external knowledge seems to be the most common KM activity, followed by communication measures (database, intranet) and training/mentoring. Big companies are more likely to have a whole range of KM activities and to have some kind of explicit or conscious KM strategy. The previous OECD survey in Germany and Denmark (Edler, 2002) shows that companies in which top management is responsible and companies which are strong innovators, respectively are active in $\mathrm{R} \& \mathrm{D}$, use $\mathrm{KM}$ practices more intensively and broadly. Overall, the present study aims to explore the totality of KM in banks, in order to get a feeling for the most important practices actually in use. Future researches in other Iranian industries may find it helpful to elaborate more on the questionnaire.

\subsection{Sample}

For empirical analysis of the relationship of KM with innovativeness, the data is gathered from the banking industry in Iran. Until currently, there is this lack of investigation for the knowledge management in the Iranian banking industry. The reason might be the recent implication of KM in this industry because the concept is new in Iran, and hence, the implementation is bare. The banking industry in this country is worthwhile, as it is the only industry in which you can find the real sense of privatization. Private Banks have been capable of producing real competition in the industry. There are cases in which the public banks did not have any other choice rather than following these banks to retain their customers.

In this study, the authors chose three Iranian banks, namely Parsian, Entrepreneur and Welfare Bank. The first two banks are privately owned, while Welfare Bank is from the public sector. We chose these three banks because the concept of KM has started being understood and they have implemented some aspects of KM practices. The rests might be in the stage of decision making about implementation. The number of 
respondents provides equal chance to both sectors to show their KM implementation. We only chose one public bank because Welfare is the only bank in this sector that practices $\mathrm{KM}$ and it has been able to achieve world-class prize from EFQM. The respondents of the study included top managers, middle managers and employees. Therefore, the study investigates and analyzes the level of practicing $\mathrm{KM}$ from different perspectives. From 200 distributed questionnaires, 121 questionnaires were collected and analyzed. The response rate of $61 \%$ provides appropriate analysis for the study.

\subsection{Questionnaire development}

The questionnaire includes thirty-three questions for measuring knowledge management practices and innovativeness. The questionnaire is the combination of the survey questions conducted by Edler (2002) for measuring KM practices and the Boselie and Pawee study in 2005 for measuring innovativeness. Based on these two studies the final questionnaire investigates the degree of knowledge management existence and implementation in policies and strategies, leadership, incentives paid, knowledge capture and acquisition, training and mentoring for sharing and acquisition of knowledge and the way that the employees communicate with each other for transferring and sharing knowledge and experiences. In order to make the questionnaire more appropriate for the case of banking in Iran, the findings are supported with an unstructured interview with the managers in charge of design and implementation of KM. In order to make the questionnaire understandable for respondents, they were translated once from English to Persian and then from Persian to English. This process was edited and checked by a professional translator.

We accompanied the questionnaire with a letter to provide respondents with the explanation of how to fill it. In addition, in order to provide better understanding to the respondents about $\mathrm{KM}$, the definition of $\mathrm{KM}$ was provided in the letter, to let them know what the study exactly mean by KM. The knowledge management in the current study purports any organized activity regarding acquirement and sharing knowledge operated in the studied banks.

The study expects that each of the three banks perform at least some types of KM practices that result in their innovativeness. The survey does not look at innovativeness specifically in terms of product and/or process but applies a general view toward that. This is because in the banking industry, the concentration is more on the innovative services but providing general view on innovativeness makes the results useful for other industries, either. The items are measured on a five point from strongly agree to strongly disagree scale.

To further develop the methodology, the authors recommend that future studies work on broader sample of banks in Iran, as for this study due to the novelty of KM concept for the banks many other Iranian banks were not willing to participate. By recognizing the results of this study, many more banks in Iran will be willing to participate in similar research, practice and test the result of KM in their banks. It is also recommended that the same study be used in other industries in order to investigate the relationship of KM practices with innovativeness. In future developing the questionnaire might be useful. For instance, elaborating more on the IT questions rather just referring to databases. Asking about "smart hours", certified quality management system, standardization and international project teams are among the elements that might find interest for investigation. 


\section{Analysis of the results}

The reliability test of the questionnaire shows high degree of reliability. The Cronbach alpha for this study is 0.965 . In addition, the Cronbach alpha is calculated for each item in table 2. As the table illustrates, all Cronbach alphas are bigger than 0.7. In order to conduct the analysis, KM practices are classified into six clusters. The study names them from V1 to V6. The dependent variable is shown by V7 that represents innovativeness. Cluster one, which represents the policies and strategies for KM, consists of questions to check whether banks have: a written knowledge management policy or strategy, value system or culture intended to promote knowledge-sharing, policies or programs intended to improve worker retention. Cluster 2 consists of questions to check that knowledge management practices are; a responsibility of managers and executives, a responsibility of non-management workers, a responsibility o the knowledge officer or knowledge management unit or it is an explicit criterion for assessing worker performance. Cluster 3 includes questions to explore rewarding for knowledge sharing with monetary or nonmonetary incentives. Cluster 4 examines how knowledge is captured from other industry sources, public research institutions, detecting external knowledge by dedicated resources and by encouraging workers to participate in project teams with external experts. Cluster 5 collects information regarding training and mentoring related o KM. The questions investigate whether the organization: provides formal training related to KM practices, uses formal mentoring practices, including apprenticeships, encourages experienced workers to transfer their knowledge to new or less experienced workers or encourages workers to continue their education by reimbursing tuition fees for successfully completed work related courses. The last cluster clarifies employees' knowledge communications in banks, to see if they use regularly updated databases of good work practices, good work practices, listings of experts, preparing written documentation such as lessons learned, training manuals, and good work practices, articles for publication or facilitating collaborative work by virtual project teams.

In order to check the normal distribution of each cluster the study has employed one-sample Kolmogorov-Smirnov test. The results exposed in Table 1. Based on the results the distribution is normal.

Table 1

One-sample Kolmogorov-Smirnov test

\begin{tabular}{llrrrrrr}
\hline & & $\mathbf{v 1}$ & $\mathbf{v 2}$ & $\mathbf{v 3}$ & $\mathbf{v 4}$ & $\mathbf{v 5}$ & $\mathbf{v 6}$ \\
\hline $\mathbf{N}$ & & 121 & 121 & 121 & 121 & 120 & 121 \\
\hline Normal Parameters ${ }^{\mathbf{a}}, \mathbf{b}$ & Mean & 7.8017 & 9.9835 & 4.0826 & 7.9174 & 10.8917 & 7.3802 \\
\hline & Std. Deviation & 2.98502 & 4.01867 & 2.34374 & 2.97654 & 3.89526 & 3.17085 \\
\hline Most Extreme Differences & Absolute & .124 & .130 & .217 & .098 & .096 & .106 \\
\hline & Positive & .124 & .069 & .217 & .092 & .071 & .106 \\
\hline & Negative & -.100 & -.130 & -.187 & -.098 & -.096 & -.101 \\
\hline Kolmogorov-Smirnov $\mathbf{Z}$ & & 1.360 & 1.427 & 2.382 & 1.075 & 1.050 & 1.170 \\
\hline Asymp. Sig. (2-tailed) & & .050 & .034 & .000 & .198 & .220 & .130 \\
\hline a. Test distribution is Normal & & & & & &
\end{tabular}

a. Test distribution is Normal 


\subsection{Demographic data}

The study shows that among 121 respondents, $63 \%$ are men, $52.1 \%$ are women, and four persons did not mention about their gender. Responses show that most of our respondents have five to ten years of experience (44.6\%). Moreover, $62.8 \%$ of the respondents have bachelor degree.

The study shows that in designing and developing KM policies and strategies, $\mathrm{KM}$ is not an object of clear strategic and codified (written) planning, yet. Some fundamental revision is needed to insert KM into the bank's planning. Fig. 2 illustrates the respondents' view regarding the existence of KM in their bank's plan and strategies.

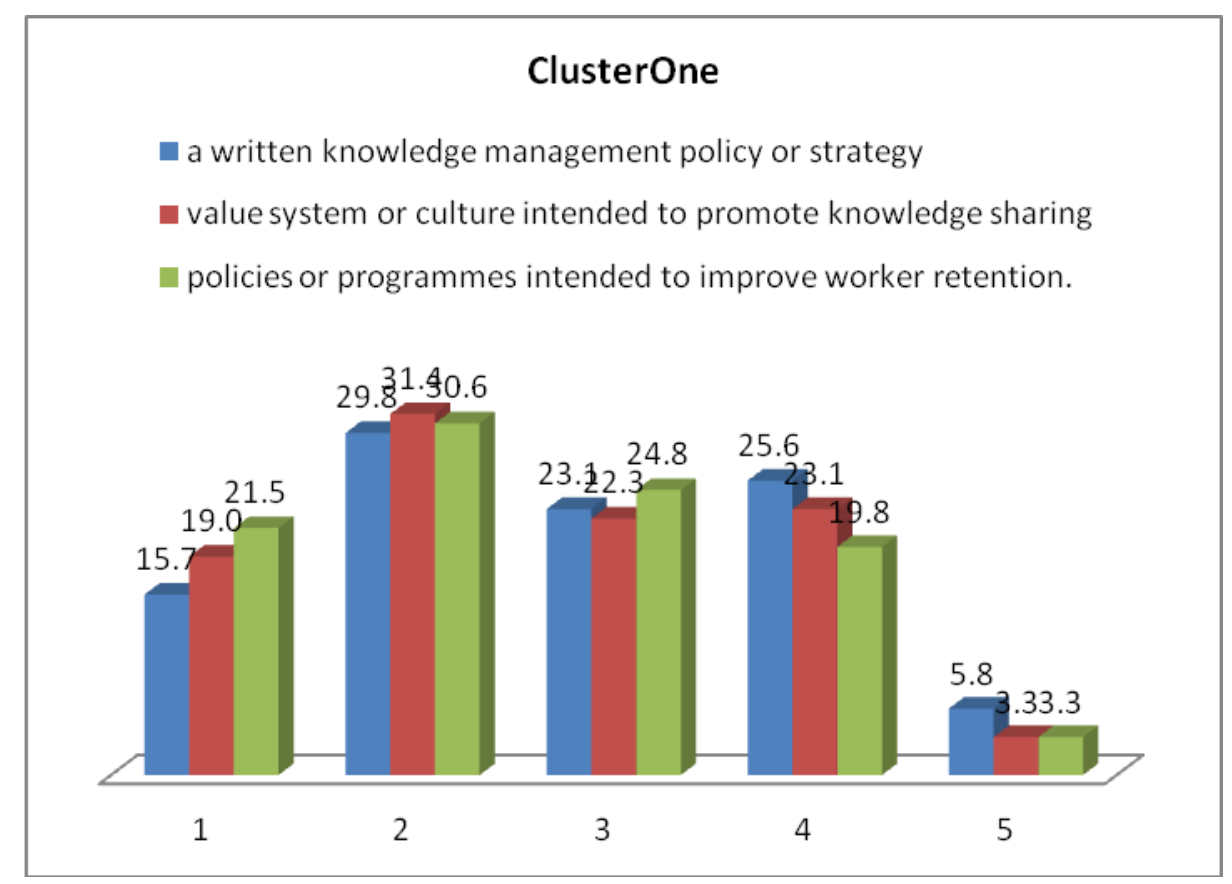

Fig. 2. Cluster 1

Moreover, the study depicts that KM in the three banks is almost $39 \%$ the responsibility of managers and executives. The result advocates the notion of disbelief in specific tasks for k-officers or k-managers in the selected bank, which might be able to propose new approaches toward managing creation and development of knowledge. Moreover, $30.57 \%$ contemplate that knowledge management is not an explicit criterion for assessing work performance. Consequently, it is not surprising to evidence that management itself is the most triggering source. It is interesting to note that KM seems to be a vague and horizontal concept still mainly overlooked by the top management. The value for "explicit criteria for assessment of workers" goes in line with the generally very low values for incentive systems. Based on the interviews with the middle and top managers in the banks, we understand that managers play the most important role in applying knowledge management in their banks. Fig. 3, shows the respondent's point of view toward managing knowledge in their banks.

In investigation the role of incentives to inspire the employees in sharing their knowledge, the respondents do not elaborate any monetary or non-monetary incentive 
system of payment to motivate them in sharing their knowledge, contribute in KM of their banks, and convert their tacit knowledge to explicit knowledge (Fig. 4).

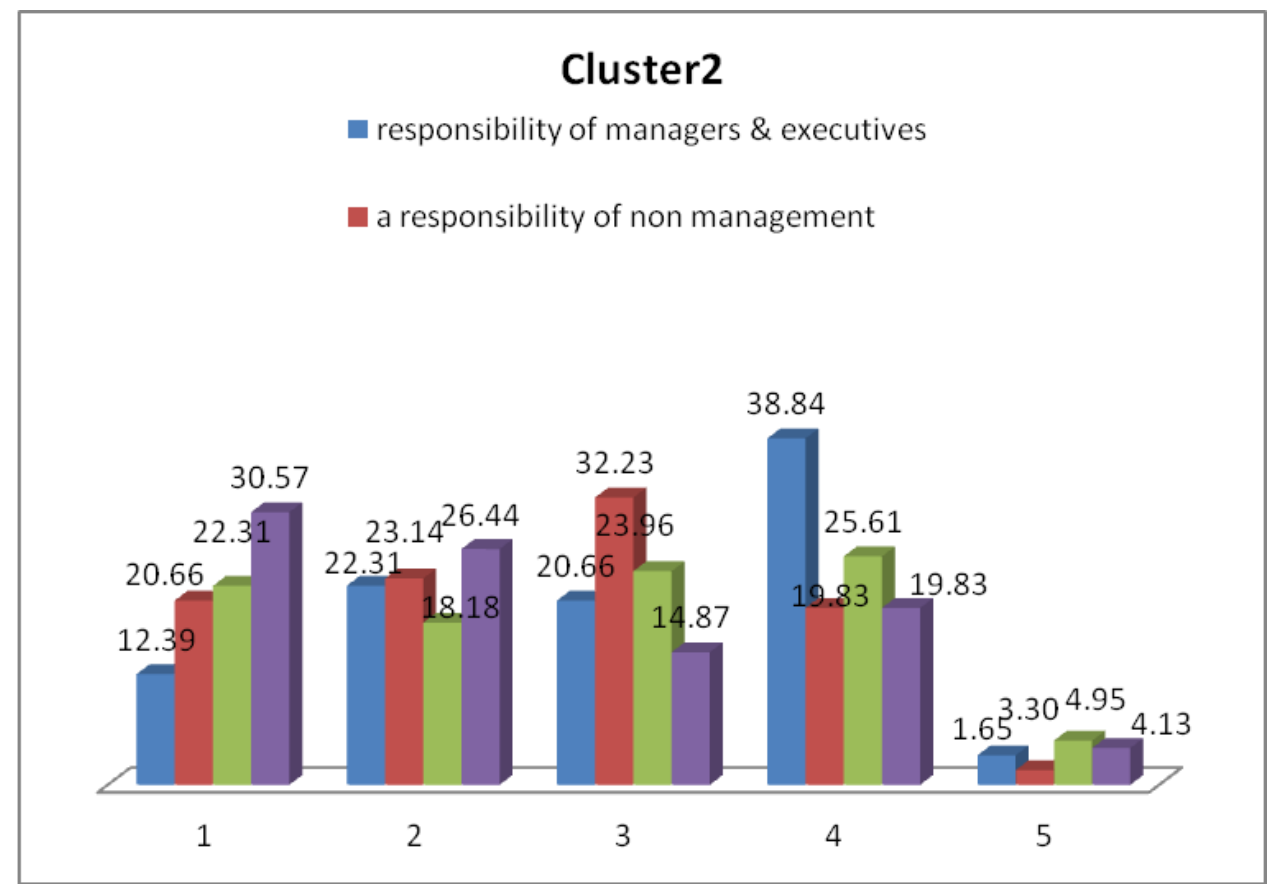

Fig. 3. Cluster 2

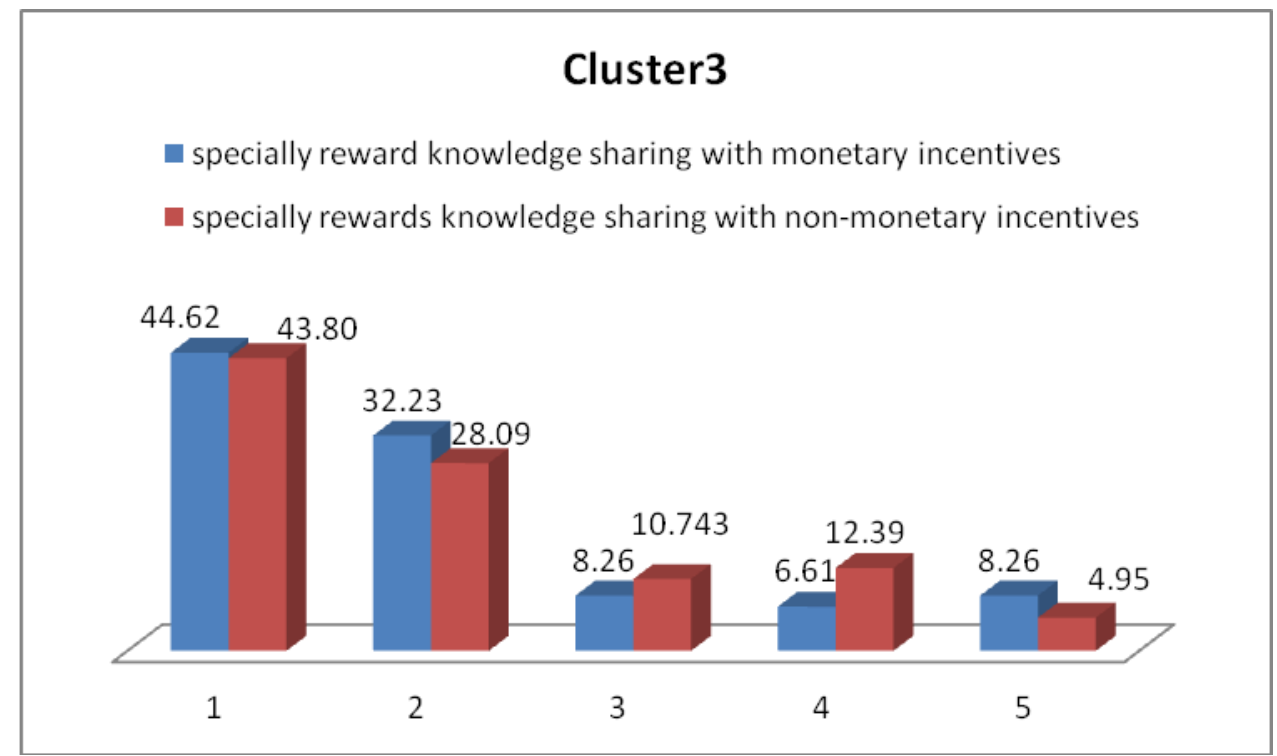

Fig. 4. Cluster 3

Looking at the channels through which the banks capture and acquire knowledge, other industry resources such as industrial associations, competitors, clients and suppliers considered as the main sources. Based on assumption, in order to cope with the growing 
dynamics and complexity of knowledge development, companies increasingly have to rely on knowledge that cannot be produced within the company itself. In fact, in some cases the acquisition of external knowledge has been defined as crucial mean for the persistence of an efficient innovative capacity of companies (Fig. 5).

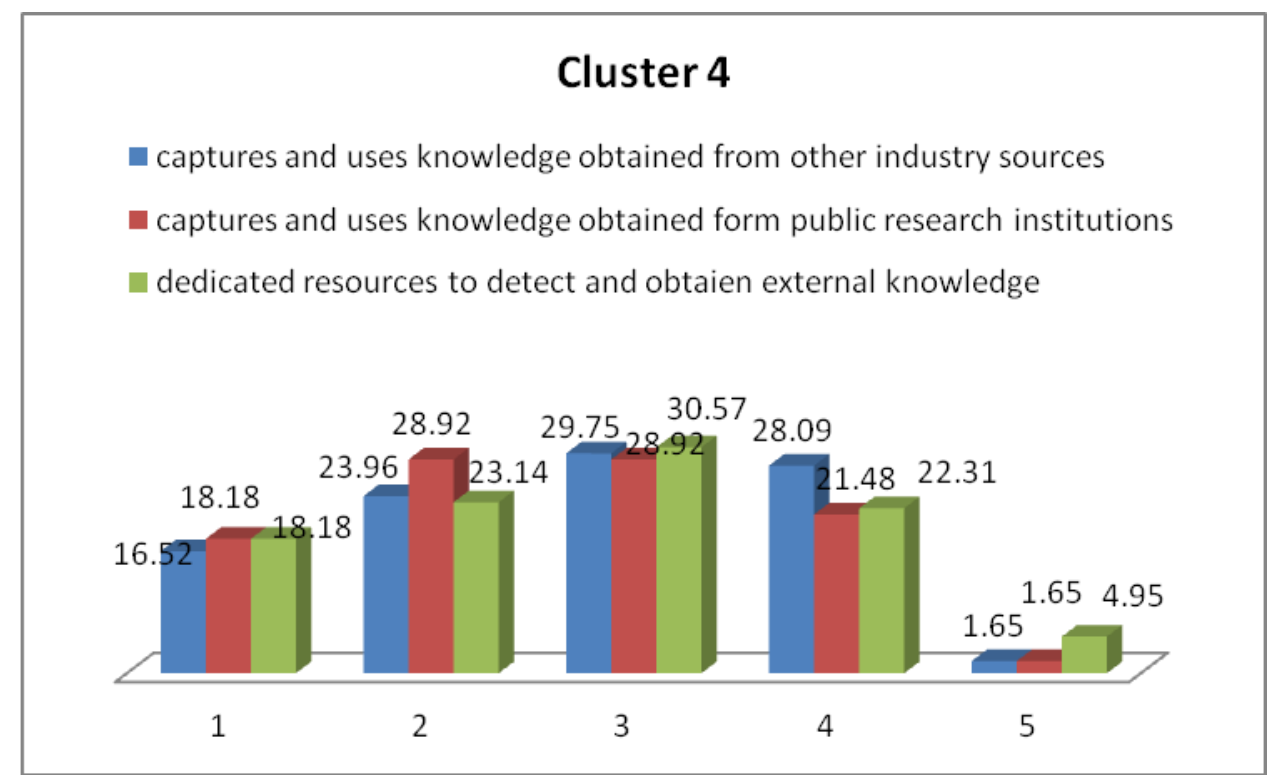

Fig. 5. Cluster 4

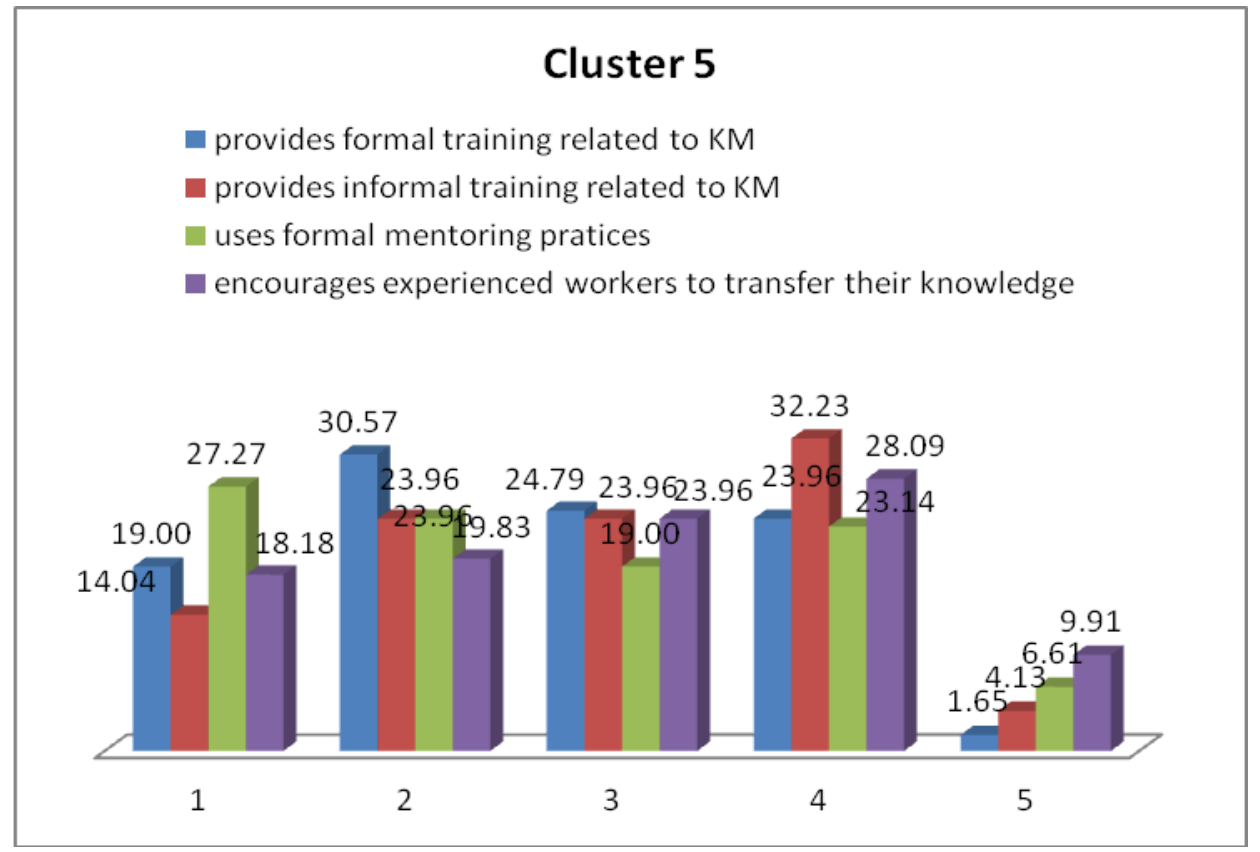

Fig. 6. Cluster 5 
Regarding training and mentoring (Fig. 6), the responses depicts informal training of $\mathrm{KM}$ in the banks. It signifies that there are not predefined plans for training of $\mathrm{KM}$ in the banks.

Finally as illustrated in Fig. 7, communications in the banks are mainly based on written documents such as lesson learned, training manuals, good work practices and articles. In concert with the situation of other industries in Iran, findings from these three banks draw on a very low degree of teamwork to communicate and share knowledge between the employees. It goes in line with the individualistic cultural dimensions of Iranians, as the people are more inclined toward individual work rather than teamwork. The high level of bureaucracy still leads the banks to redundancies. For instance, the main aim of updating databases is to keep the employees informed about the previous projects, letting them know about the lesson learnt and inspiring them to contribute in knowledge management of their organizations, but the centralized decision-makings and high level of bureaucracy impedes the banks from achieving these goals.

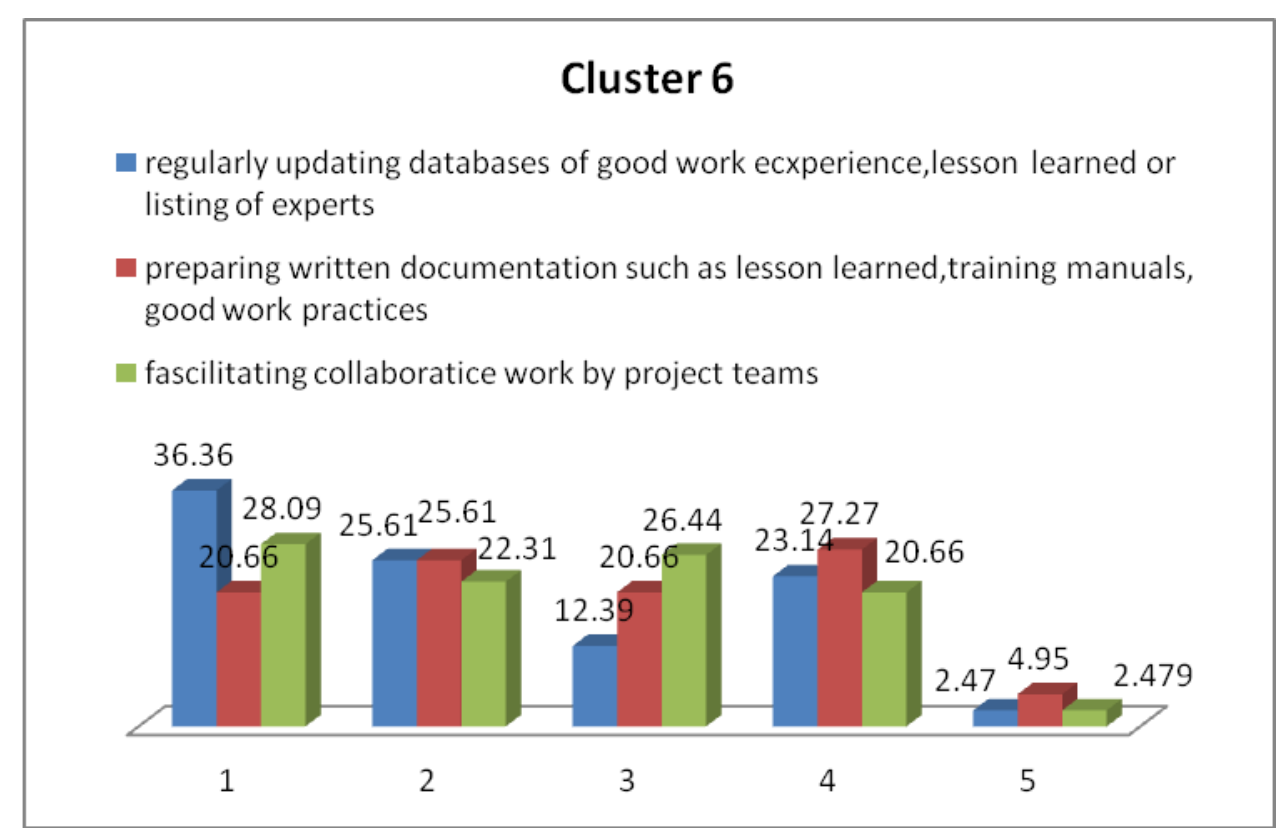

Fig. 7. Cluster 6

The result of the relationship between KM practices in the banks with innovativeness shows that through practicing KM employees view uncertainty as an opportunity and not as a risk. It resonates promising opportunity for the banks to benefit from their employee's innovative ideas. Collegiality character of banks managers paves the way for the employees to approach them with their novel ideas. It is also in line with the acceptable level of the opportunity provided by the banks to employees in developing their creativity. Overall, based on the six defined clusters, the study concludes that training and mentoring is playing more prominent role among other KM practices.

Table 2 shows the overall descriptive statistics for the six clusters. Each cluster is represented as V1 to V6. 
Table 2

Descriptive statistics for the six clusters

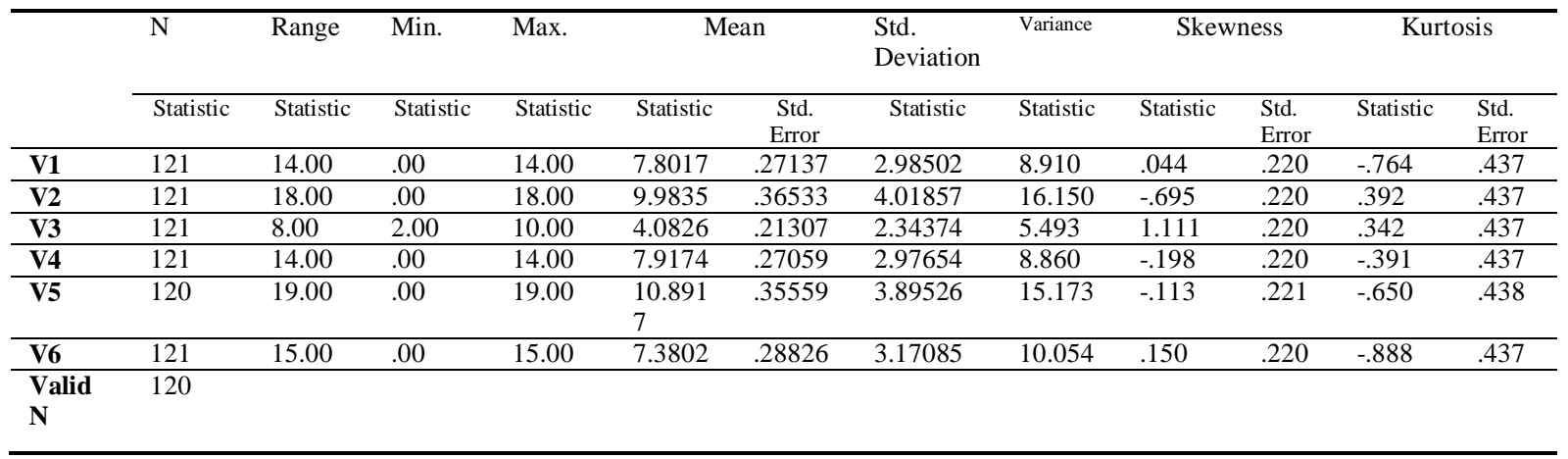

Finally, Table 3 elucidates the significant relationship between the six clusters of $\mathrm{KM}$ practices and innovativeness in the three investigated Iranian banks. As the table shows, all six hypotheses mentioned at the beginning of the study are supported and approved. This table elaborates on the correlation of each item, based on which the innovativeness is measured, with each of the clusters of KM practices. Based on the table, the correlation between cluster five and giving rewards to innovators, as one of the items of innovativeness (V7) with the correlation of $70.4 \%$, is the most significant. Thus, the study concludes that if Iranian banks apply KM through training and mentoring practices, this will lead mostly to the innovativeness comparing to other KM practices. The problem solving capabilities of knowledge employees lie in their educational background, professional training, creativity, and motivation. Approved and focused training programs help in the production of new knowledge that thereby leads to innovative solutions and the management of change (Egbu, 2006). Mentoring provides a mean for firms to share knowledge, encourage learning, and build intellectual capital (Allen, McManus, \& Russell, 1999; Eddy, Tannenbanm, Lorenzet, \& Smith-Jentsch, 2005; Hezlett, 2005; Lankau \& Scandura, 2002; Mullen \& Noe, 1999; Swap, Leonard, Shields, \& Abrams, 2001). Peer mentoring provides a mechanism for sharing job-related knowledge (Allen, McManus, \& Russell, 1999; 1999; Eby, 1997; Eddy, Tannenbanm, Lorenzet, \& SmithJentsch, 2005; Ensher, Thomas, \& Murphy, 2001). Managers need to know that it s essential for their employees to update their knowledge, periodically. Because the knowledge should be upgraded based on the environmental changes. The applied training and mentoring should be in line with awarding the employees with monetary or nonmonetary rewards. This is the situation where employees understand the result of their contribution to the organizational goals. Employees of the bank think that innovativeness should be practiced through providing rewards to innovators. The second vital knowledge management practice for innovative purposes of the organizations is the internal method of communication. Different means of communication directs managers to find different solutions to the problems. This will not happen unless Iranian banks deeply understand the importance of communication and teamwork by inserting it in their organizational culture. 
Table 3

Spearman correlation of each cluster with innovative practices

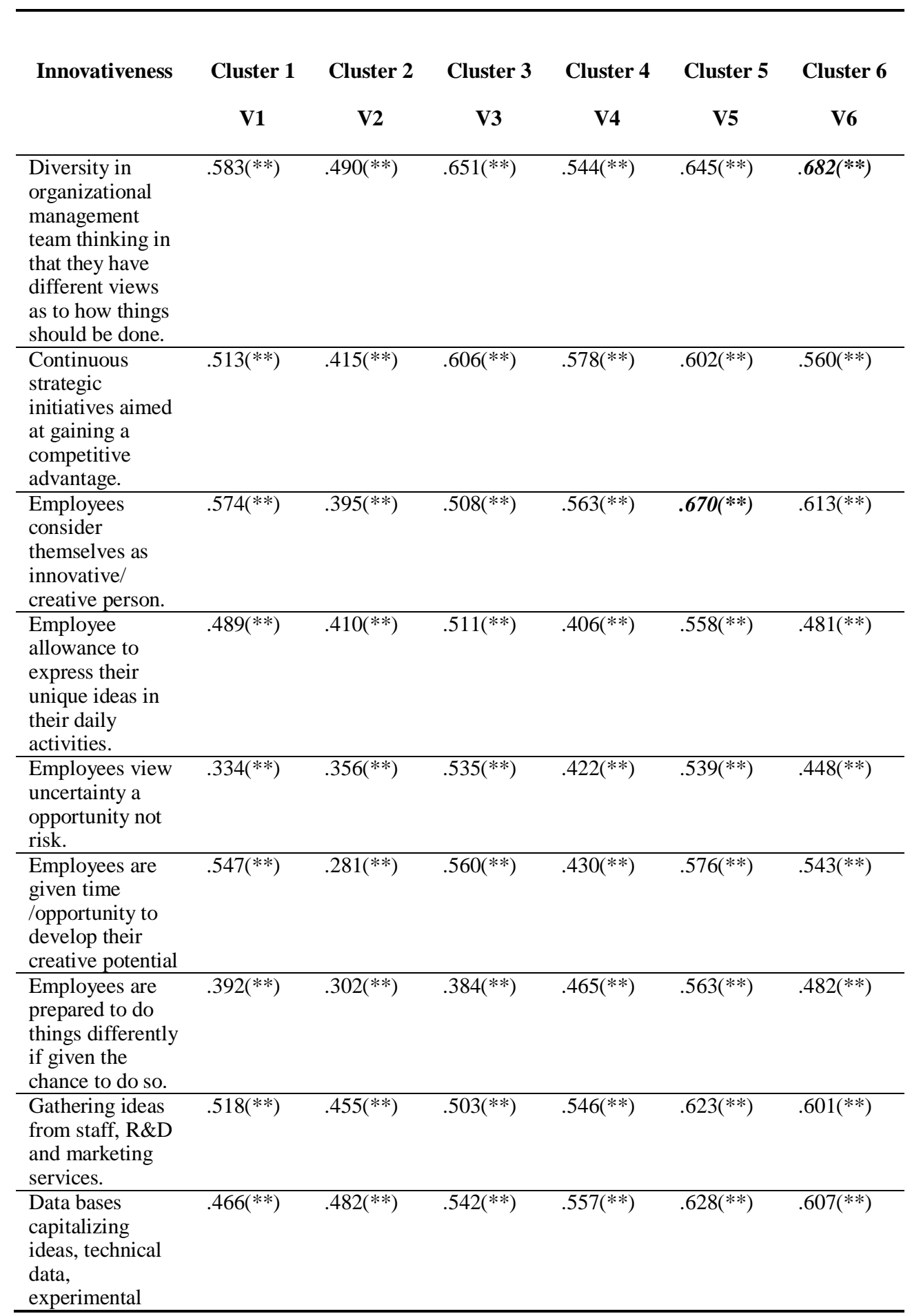




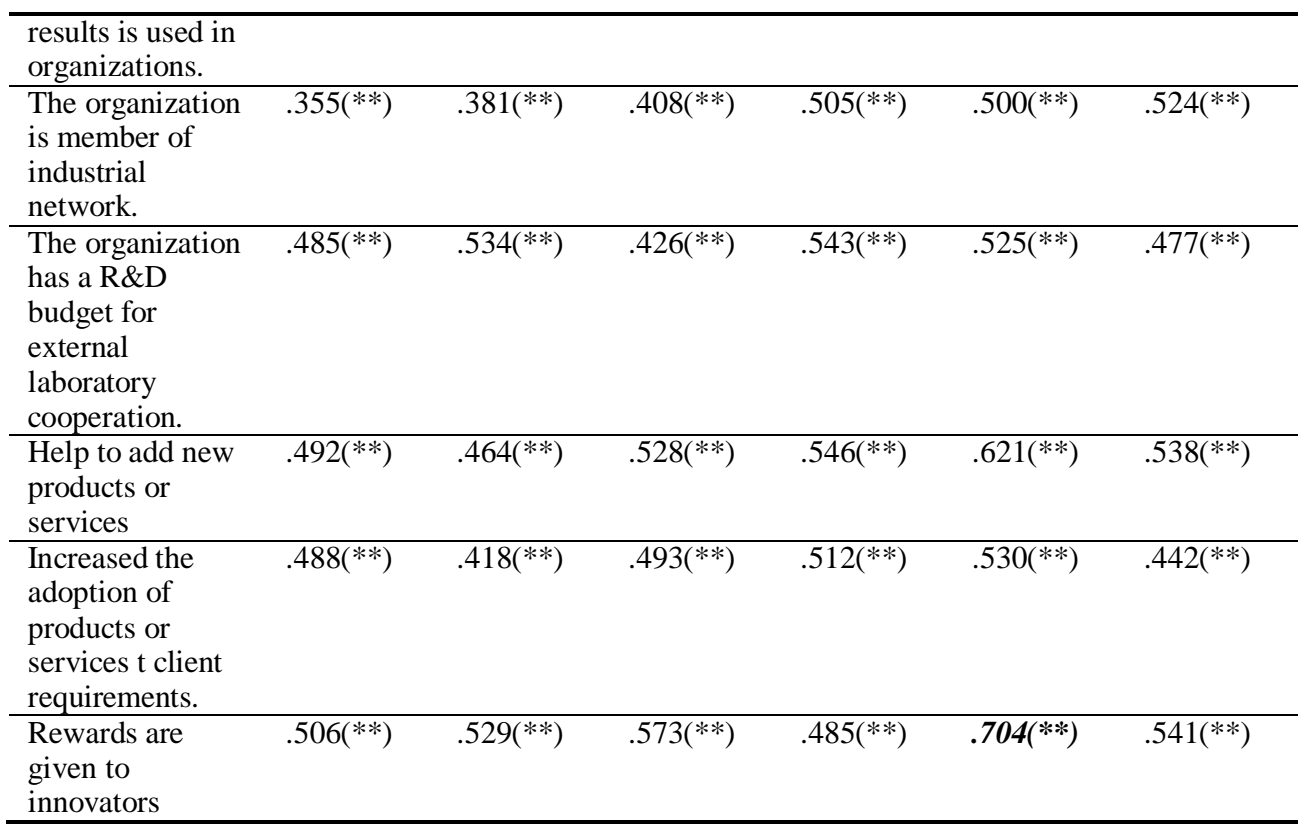

Based on the above table the most significant correlation is with V5 (training and mentoring) and V7 (innovativeness) with $74.9 \%$.

In overall view, the study shows the relationship between innovativeness as dependent variable (V7) and the six other clusters constituting knowledge management practices as independent variables (V1-V6) in below Table 4 (based the correlation coefficients):

Table 4

Regression coefficient

\begin{tabular}{cccccc}
\hline Model & \multicolumn{2}{c}{$\begin{array}{c}\text { Unstansdardized } \\
\text { Coefficients }\end{array}$} & $\begin{array}{c}\text { Standardized } \\
\text { Coefficients }\end{array}$ & t & Sig \\
\cline { 2 - 4 } & $\mathbf{B}$ & Std. Error & Beta & & \\
\hline Constant & 4.719 & 2.478 & & 1.904 & .059 \\
\hline V1 & .100 & .335 & .023 & .298 & .767 \\
\hline V2 & .305 & .224 & .096 & 1.361 & .176 \\
\hline V3 & 1.129 & .422 & .223 & 2.890 & .005 \\
\hline V4 & .513 & .340 & .118 & 1.510 & .134 \\
\hline V5 & 1.158 & .265 & .348 & 4.367 & .000 \\
\hline V6 & .757 & .350 & .187 & 2.162 & .033 \\
\hline
\end{tabular}

The equation that shows the proposed relationship for the current article based on R-square come is as follow:

$($ Innovativeness $) V 7=4.719+V 1+0.305$ V2 $+1.219 \mathrm{V3}+0.513 \mathrm{~V} 4+1.158 \mathrm{~V} 5+0.757 \mathrm{V6}$ 


\section{Conclusion}

The result of this study demonstrates the investigation of six different clusters constituting KM practices in three Iranian banks. These banks were chosen from private and public sectors based on the fact that they are the only banks which have initiated practicing knowledge management and the rest have not come to this belief, yet. Results show that managers are prominent in practicing KM. This manifest centralized decisionmaking practiced in Iranian banking system. The study posits informal training in sharing knowledge as the essential practice in fostering innovativeness in the organization. Working on the other aspects such as IT systems, for the ease of strong and sharing experiences or lesson learnt are useful. The study finds out that knowledge is captured from industrial resources, such as industrial associations, competitors, clients and suppliers in three investigated banks. In addition, banks can use classical codified sources (journals) which are still the most important sources, followed by interactive events (fairs) and internet. Direct contacts with external experts are also crucial. This communication makes the bank adopting with the changing environment and act proactively.

Even though the governmental control dominates the majority of the Iranian industries, by emersion and growth of private banks, the services and products offered, the public sector has no other way rather than reactively respond to them through imitating their standards. The reason might be the supremacy of real competition in Iranian banking industry comparing to others that merely bear the title of privatization. Based on the findings the authors recommend rewarding to innovators in order for them to see the result of their creative way of thinking.

These results provide suggestions for other banks in both private and public sector, which are still in the first stage of practicing KM. It shows how beneficial KM is to make them more innovative and as a result more competitive in the industry. Research infancy on implementation and monitoring the practice of $\mathrm{KM}$ in banking industry, the governmental dominance and the failed privatization in different industries requires profound consideration. Moreover, establishing creative way of thinking among managers and their belief about long-term orientation in decision-makings, stabilizing decentralized decision-makings, providing motives to the innovators and proper appraisal system, nurturing teamwork rather than individualistic approach in Iranian organizations need more investigation. These mentioned areas of studies will facilitate the practice of $\mathrm{KM}$ in banking and other industries and prove the importance of managerial way of thinking, existence of real competition and benefits the industries can gain from diminishing governmental interference and dominance. Being the first study on the relationship of KM with innovativeness in Iran banking industry, future researches can continue this work with the emergence of other banks that start practicing KM. In addition, the same study can be replicated on other industries.

\section{References}

Alavi, M., \& Leidner, D. E. (2001). Review: Knowledge management and knowledge management systems: Conceptual foundations and research issues. MIS Quarterly, 25(1), 107-136.

Allen, T. D., McManus, S. E., \& Russell, J. E. A. (1999). Newcomer socialization and stress: Formal peer relationships as a source of support. Journal of Vocational Behavior, 54, 453-470.

Audretsch, D. B., \& Thurik, A. R. (2004). The model of the entrepreneurial economy. International Journal of Entrepreneurship Education, 2(2), 143-166. 
Azudin, N., Ismail, M., \& Taheral, Z. (2009). Knowledge sharing among workers: A study on their contribution through informal communication in Cyberjaya, Malaysia. Knowledge Management \& E-Learning: An International Journal, 1(2), 139-162.

Benbya, H., Passianten, G., \& Belbaly, N. (2004). Corporate portal: A tool for knowledge management synchronization. International Journal of Information Management. 24(3), 201-220.

Boisot, M. H., (1995). Is your firm a creative destroyer? Competitive learning and knowledge flows in the technological strategies of firms. Research Policy 24(4), 489507.

Boselie, P., \& Paauwe, J. (2005). Human resource function competencies in European companies. Personnel Review, 34(5), 550-566.

Butler, T., \& Murphy, C. (2004). Implementing knowledge management systems in public sector organizations: A case study of critical success factors. Retrieved from http://www.cos.ufri.br.

Chirico, F. (2008). Knowledge accumulation in family firms. Evidence from four case studies. International Small Business Journal, 26(4), 443-462.

Chu, K. W., Wang, M., \& Yuen, A. H. K. (2011). Implementing knowledge management in school environment: Teachers' perception. Knowledge Management \& E-Learning: An International Journal, 3(2), 139-152.

Cijsouw, R. S., Jorna, R. J., Rakhorst, G., \& Verkerke, G. J. (2007). Omissions in managing knowledge in innovation processes or how to handle knowledge, humans and tasks: A semio-cognitive approach. In P. J. Charrel \& D. Galarreta (Eds,), Project Management and Risk Management in Complex Projects: Studies in Organizational Semiotics (pp. 15-45). Springer.

Clutterbuck, D. (2001). Everyone needs a mentor: Fostering talent at work. Institute of Personnel and Development, London.

Coombs, M. K. (1998). Honest follow-through needed on this project. The Washington Times, March 24. $\quad$ Retrieved rom http://www.mathematicallycorrect.com/honestft.htm.

Corbett-Etchevers, I., \& Mounoud, E. (2011). Management in multinational company a narrative framework for management ideas: Disclosing the plots of knowledge. Management Learning, 42(2), 165-181.

Darroch, J. (2005), Knowledge management, innovation and firm performance. Journal of Knowledge Management, 9(3), 101-115.

Davenport, T. H., De Long, D. W., \& Beers, M. C. (1997). Building successful knowledge management projects. Center for Business Innovation Working Paper. Ernst \& Young LLP.

Earl, M. J., \& Scott, I. (1999). What is a chief knowledge officer? Sloan Management Review, 40(2), 29-38.

Eby, L. T. (1997). Alternative forms of mentoring in changing organizational environments: A conceptual extension of the mentoring literature. Journal of Vocational Behavior, 51,125-144.

Eddy, E. R., Tannenbanm, S. I., Lorenzet, S. J., \& Smith-Jentsch, K. A. (2005). The influence of a continuous learning environment on peer mentoring behaviors. Journal of Managerial Issues, 17(3), 383-395.

Edler, J. (2002). German pilot study. Fraunhofer institute for systems and innovation research, Karlsruhe. Retrieved from www.oecd.org/dataoecd/23/30/2756424.pdf .

Egbu, C. (2006). Knowledge production and capabilities-their importance and challenges for construction organizations in China. Journal of Technology Management in China, 1(3), 304-321.

Ensher, E. A., Thomas, C., \& Murphy, S. E. (2001). Comparison of traditional, step- 
ahead, and peer mentoring on Protages' support, satisfaction, and perceptions of career success: A social exchange perspective. Journal of Business and Psychology, $15,419-438$.

Frost, A. (2011). Knowledge management tools (mentoring). Retrieved from http://www.knowledge-management-tools.net/mentoring.

Fullan, M. (2001a). Leading in a culture of change. San Francisco: Jossey-Bass.

Fullan, M. (2001b). The new meaning of educational change (3rd ed.). New York: Teachers College Press.

Gold, A. H., Malhotra, A., \& Segars, A. H. (2001). Knowledge management: An organizational capabilities perspective. J Manage Inf Syst, 18(1), 185-214.

Grant, R. M. (1996a). Prospering in dynamically competitive environments: Organizational capability as knowledge integration. Organization Science, 7(4), 375386.

Grant, R. M. (1996b). Toward a knowledge-based theory of the firm. Strategic Management Journal, 17, 109-122.

Hall, B. H., \& Mairesse, J. (2006). Empirical studies of innovation in the knowledge driven economy. Economics of Innovation and New Technology, 15(4/5), 289-299.

Hargadon, A. B. (1998). Firms as knowledge brokers: Lessons in pursuing continuous innovation. California Management Review, 40(3), 209-227.

Heisig, P. (2009). Harmonisation of knowledge management - comparing $160 \mathrm{KM}$ frameworks around the globe. Journal of Knowledge Management, 13(4), 4-31.

Helfert, M. (2002). Proaktives Datenqualitätsmanagement in Data-Warehouse-Systemen: Qualitätsplanung und Qualitätslenkung. Dissertation St. Gallen. Logos Velrage, Berline.

Hezlett, S. A. (2005). Proteges' learning in mentoring relationships: A review of the literature and an exploratory case study. Advances in Developing Human Resources, 7(4), 505-526.

Jaffe, A. B. (1986), Technological opportunity and spillovers of R\&D: Evidence from firm's patent, profits, and market value. American Economic Review, 76(5), 9841001.

Klett, F. (2010). The design of a sustainable competency-based human resources management: A holistic approach. Knowledge Management \& E-Learning: An International Journal, 2(3), 278-292.

Lankau, M. J., \& Scandura, T. A. (2002). An investigation of personal learning in mentoring relationships: Content, antecedents, and consequences. Academy of Management Journal, 45(4), 779-790.

Lengnick-Hall, M. L., \& Lengnick-Hall, C. A. (2002). Human resource management in the knowledge economy. San Francisco: Berret-Koehler publishers.

Levitt, B., \& March, J. G., (1988). Organizational learning. Annual Review of Sociology 14, 319-340.

Liebeskind, J. P. (1997). Keeping organizational secrets: Protective institutional mechanisms and their costs. Industrial and Corporate Change, 6(3), 623-663.

Mullen, E. J., \& Noe. R. A. (1999). The mentoring information exchange: When do mentors seek information from their Proteges? Journal of Organizational Behavior, 20(2), 233-242.

Muller, A., Valikangas, L., \& Merlyn, P. (2005). Metrics for innovation: guidelines for developing a customized suite of innovation metrics. Strategy and Leadership, 33, $27-45$.

Nonaka, I., \& Takeuchi, H. (1995). The knowledge-creating company: How Japanese companies create the dynamics of innovation (pp. 284). New York: Oxford University Press.

OECD. (2003). Genetic Inventions, IPRs and Licensing Practices: Evidence and Policies. 
OECD, Paris

Ojanen, V. (2007). On the innovative capacity of technology related knowledge-intensive business services. International Journal of Entrepreneurship and Innovation Management, 10(2), 162-177.

Pagell, M. (2004). Understanding the factors that enable and inhibit the integration of operations, purchasing and logistics. Journal of Operations Management, 22(5), 459487.

PricewaterhouseCoopers Human Resource Services. (2006). Key trends in human capital:Aglobalperspective. Retrieved from http://www.pwc.co.uk/eng/publications/Key_trends_in_human_capital.html.

Probst, G., Raub, S., \& Romhardt, K. (1999). Wissen managen. Wie Unternehmen ihre wertvollste Ressource optimal nutzen (3rd ed.) (p. 46). Frankfurt am Main, Wiesbaden, Gabler-Verlag.

Ruekert, R. W., \& Walker, Jr. O. C. (1987). Marketing's interaction with other functional units: a conceptual framework and empirical evidence. Journal of Marketing, 51(1), $1-19$.

Sanders, N. R., \& Premus, R. (2005). Modeling the relationship between firm IT capability, collaboration and performance. Journal of Business Logistics, 26(1), 1-2.

Sarin, S., \& McDermott, C. (2003). The effect of team leader characteristics on learning, knowledge application, and performance of cross-functional new product development teams. Decis Sci, 34(4), 707-739.

Semar, W. (2004). Incentive systems in knowledge management to support cooperative distributed forms of creating and acquiring knowledge. Proceedings of the International Conference on Information and Knowledge Engineering - IKE'04 (pp. 406-411). Las Vegas: CSREA Press.

Swan, J., Newell, S., Scarbrough, H., \& Hislop, D. (1999). Knowledge management and innovation: Networks and networking. Journal of Knowledge Management, 3(4), 262-275.

Swap, W., Leonard, D., Shields, M., \& Abrams, L. (2001). Using mentoring and storytelling to transfer knowledge in the workplace. Journal of Management Information Systems, 18(1), 95-114.

Turban, E., Leidner, D., McLean, E., \& Wetherbe, J. (2008). Information technology for management (6th ed.). John Wiley \& Sons, New Jersey.

Weisberg, R. W. (2006). Expertise and reason in creative thinking: evidence from case studies and the laboratory. In J. C. Kaufman \& J. Baer (Eds.), Creativity and reason in cognitive development, (pp. 7-42). Cambridge, England: Cambridge University Press.

Wu, J.-H., \& Wang, Y.-M. (2006). Measuring KMS success: A respecification of the DeLone and McLean's model. Information \& Management, 43(6), 728-739.

Yli-Renko, H., Autio, E., Sapienza, H. J. (2001). Social capital, knowledge acquisition, and knowledge exploitation in young technology-based firms. Strategic Manage J, 22(6/7),587-613.

Zack, M. H. (1999). Developing a knowledge strategy. California Management Review, 41(3), 125-145.

Zhou, J., Chen, S., \& Jin, L. (2009). Using digital resources for the ECE curriculum in China: Current needs and future development. Knowledge Management \& ELearning: An International Journal, 1(4), 285-294. 